\title{
Association of the invasiveness of colon cancer with the expression of $\mathrm{C} / \mathrm{EBP} \alpha$
}

\author{
WEI LI $^{1 *}$, LIANG-JUN JIANG ${ }^{2 *}$, XIAO-JUN ZHOU ${ }^{1}$, XIAN-ZHOU LU ${ }^{1}$, LONG-FEI LIU ${ }^{1}$ and SONG WANG ${ }^{1}$ \\ Departments of ${ }^{1}$ General Surgery and ${ }^{2}$ Gastroenterology, Affiliated Nanhua Hospital, \\ University of South China, Hengyang, Hunan 421002, P.R. China
}

Received January 16, 2017; Accepted May 5, 2017

DOI: $10.3892 / \mathrm{ol} .2018 .9755$

\begin{abstract}
The present study aimed to investigate the association of the invasiveness of colon cancer (CC) with the expression of CCAAT/enhancer binding protein $\alpha(\mathrm{C} / \mathrm{EBP} \alpha)$. Immunohistochemistry was performed to determine the expression of $\mathrm{C} / \mathrm{EBP} \alpha$ in the cancer and adjacent tissue samples from 48 patients with CC. A pCDGFP-C/EBP $\alpha$ eukaryotic expression vector was constructed, and a wound-healing assay was performed to observe the effect of transfection on the migration of SW480 cells. In addition, the expression levels of tumor invasion-associated proteins, including Kruppel-like factor 5 (KLF5), matrix metallopeptidase (MMP)-2, MMP-9, and E-cadherin (ECD) were detected subsequent to transfection. Immunohistochemistry analysis demonstrated that the rate of low $\mathrm{C} / \mathrm{EBP} \alpha$ expression in normal tissue was $6.25 \%$, whereas the rate in $\mathrm{CC}$ tissues was $68.75 \%$; this difference was statistically significant $(\mathrm{P}<0.05)$. The patients with lower $\mathrm{C} / \mathrm{EBP} \alpha$ expression exhibited statistically larger tumor diameters, more advanced tumor-node-metastasis (TMN) stages and a greater likelihood of lymph node metastasis. The overexpression of $\mathrm{C} / \mathrm{EBP} \alpha$ significantly reduced the mobility of SW480 cells, and the expression of KLF5, MMP-2 and MMP-9 was reduced, whereas the expression of ECD was increased. In conclusion, $\mathrm{C} / \mathrm{EBP} \alpha$ was downregulated in $\mathrm{CC}$ tissue samples, and associated with the TMN stage and metastasis of $\mathrm{CC}$; in addition, the overexpression of $\mathrm{C} / \mathrm{EBP} \alpha$ significantly reduced the invasiveness of $\mathrm{CC}$ cells. This may be significant for the diagnosis and treatment of $\mathrm{CC}$ in the future.
\end{abstract}

Correspondence to: Dr Xian-Zhou Lu or Dr Song Wang, Department of General Surgery, Affiliated Nanhua Hospital, University of South China, 336 Dongfeng South Road, Zhuhui, Hengyang, Hunan 421002, P.R. China

E-mail: docweili@126.com

E-mail:wangmomo1983@sohu.com

${ }^{*}$ Contributed equally

Key words: colon cancer, invasiveness, CCAAT/enhancer binding protein $\alpha$, expression

\section{Introduction}

The morbidity and mortality rates for colon cancer (CC) rank third among all types of malignant tumor, worldwide (1). $\mathrm{CC}$ incidence is increasing annually, and occurring in increasingly younger populations $(2,3)$. The early stages of $\mathrm{CC}$ are frequently asymptomatic, meaning that invasion and metastasis have often already occurred when CC is diagnosed, thus affecting how effectively the disease can be clinically treated. The identification of CC-specific molecular markers and strategies to inhibit tumor invasion has crucial importance towards its early diagnosis, and potentially in the development of gene-targeted therapy.

CCAAT/enhancer binding protein $\alpha(\mathrm{C} / \mathrm{EBP} \alpha)$ is widely expressed in human tissue samples (4), particularly in the liver, lung, adipose tissue and placenta $(5,6) . \mathrm{C} / \mathrm{EBP} \alpha$ is a transcription factor that has been demonstrated not only to serve a role in inhibiting cell proliferation and promoting cell differentiation $(7,8)$, but also in inhibiting the invasion and metastasis of tumor cells (9). Therefore, it demonstrates the typical characteristics of a tumor suppressor gene.

The present study examined $48 \mathrm{CC}$ tumor specimens and determined their $\mathrm{C} / \mathrm{EBP} \alpha$ expression level, as well as the association between its expression and clinicopathological parameters. Then the effect of the induced overexpression of $\mathrm{C} / \mathrm{EBP} \alpha$ on the invasiveness of the CC cell line, SW480, was investigated, with the aim of providing a theoretical basis for novel molecular markers and the gene-targeted therapy of CC.

\section{Patients and methods}

Clinical data. A total of 48 patients with $\mathrm{CC}$ admitted into the Affiliated Nanhua Hospital (Hengyang, China) between October 2013 and November 2014 were selected, including 30 males and 18 females aged 32 to 78 years, with a mean age of 54.2 years. A total of 22 cases exhibited a tumor diameter $\leq 5 \mathrm{~cm}$, whereas the remaining 26 cases were $>5 \mathrm{~cm} ; 22$ cases were stage $\mathrm{T} 1$ or 2 , and 26 cases were in stage $\mathrm{T} 3$ or 4 , according to the National Comprehensive Cancer Network Guidelines for Colon Cancer Tumor-Node-Metastasis (TNM) staging system (10); 21 cases had no lymph node metastasis, whereas 27 cases were lymph node metastasis-positive. All patients were diagnosed as $\mathrm{CC}$ and had not received chemotherapy prior to surgery. Tumor and adjacent normal tissue samples 
(distance from the tumor margin, $>5 \mathrm{~cm}$ ) were extracted from all patients, fixed in formalin, and embedded in paraffin. The study was conducted in accordance with the declaration of Helsinki, and was approved by the Ethics Committee of the University of South China (Hengyang, China). Written informed consent was obtained from all participants.

Immunohistochemistry. Representative formalin fixed, paraffin-embedded tissue blocks were selected from each sample. Sections of 5- $\mu \mathrm{m}$ thickness were cut, deparaffinized by xylene (twice) for $10 \mathrm{~min}$ and rehydrated through a graded ethanol series $(95,85,75$ and $50 \%$, for 5 min each). Antigen retrieval was performed by heating the slides in citrate buffer (Beijing Solarbio Science \& Technology Co., Ltd., Beijing, China) at $98^{\circ} \mathrm{C}$ for $30 \mathrm{~min}$ in a water bath. Endogenous peroxidase activity was quenched for $10 \mathrm{~min}$ with a peroxidase blocking reagent (Dako; Agilent Technologies, Inc., Santa Clara, CA, USA). The sample was incubated with primary antibodies, including anti- $\mathrm{C} / \mathrm{EBP} \alpha$ (dilution, 1:200; cat. no. sc-61; Santa Cruz Biotechnology, Inc., Dallas, $\mathrm{TX}, \mathrm{USA})$ at $4^{\circ} \mathrm{C}$ overnight, and then were incubated with secondary antibodies anti-mouse IgG (dilution, 1:200; cat. no. A21010; Amyjet Scientific, Wuhan, China) for $30 \mathrm{~min}$ at $37^{\circ} \mathrm{C}$. Antibody staining was visualized using the ChemMate Envision detection system (Dako; Agilent Technologies, Inc.). Sections were counterstained with Meyer's hematoxylin solution at room temperature for 30-60 sec. Negative controls were run simultaneously using a pre-immune serum without any antibody diluted to 1:10 and 1:5 (Thermo Fisher Scientific, Inc., Waltham, MA, USA). The C/EBP $\alpha$ IHC signals were scored on the following scale, considering the proportion of cells stained as follows: Score 0, no cells stained; score 1, weak or absent nuclear staining in $<5 \%$ of cells; score 2 , nuclear staining in $5-25 \%$ of the cells; score 3 , nuclear staining in $26-50 \%$ of the cells; score 4 , nuclear staining in $>50 \%$ of the cells. Two observers quantified the staining results independently.

Plasmid construction. A pCDGFP-C/EBP $\alpha$ eukaryotic expression plasmid was constructed. PrimeSTAR polymerase was used to amplify the $\mathrm{C} / \mathrm{EBP} \alpha$ coding sequence from a human $\mathrm{C} / \mathrm{EBP} \alpha$-containing cDNA library using polymerase chain reaction (PCR) with the following primers: Forward, CGC GGATCCGCGAGCCACCATGGAGTCGGCCGACT and reverse, CCGGAATTCCGGCGCGCAGTTGCCCATG. Pre-denaturation at $95^{\circ} \mathrm{C}$ for $10 \mathrm{~min}$, denaturation at $95^{\circ} \mathrm{C}$ for $10 \mathrm{sec}, 62^{\circ} \mathrm{C}$ for $30 \mathrm{sec}$ and extension at $72^{\circ} \mathrm{C}$ for $32 \mathrm{sec}$ for 40 cycles. The PCR products were then purified by agarose gel electrophoresis followed by double-enzyme digestion (BamHI and EcoRI); the pCDGFP vector was prepared with the same double-enzyme digestion. T4 ligase was used to connect the digested PCR products and the vector at $16^{\circ} \mathrm{C}$ for $12 \mathrm{~h}$, followed by plasmid transformation into TG1 competent $E$. coli cells. The transformed cells were then incubated on inverted ampicillin agar plates at $37^{\circ} \mathrm{C}$ until clones were visible $(\sim 10 \mathrm{~h})$. A sterilized toothpick was used to select several monoclones and seed them into LB medium with ampicillin for incubation with shaking $\left(37^{\circ} \mathrm{C}, 250 \mathrm{RPM}\right)$ until the broth appeared cloudy $(\sim 10 \mathrm{~h})$, when the bacteria were collected. The alkaline lysis method was used to extract the plasmids. The extracted plasmids were digested with $B a m \mathrm{HI}$ and $E c o$ RI and separated with gel electrophoresis for verification; the plasmids were then DNA sequenced for further confirmation.

Cell culture. The human CC cell line SW480 was purchased from Biowit Technologies Ltd. (Shenzhen, China), and stored in liquid nitrogen until the experiments. The cells were then cultured in 5\% FBS (cat. no. 10099158; Thermo Fisher Scientific, Inc.), 10\% FBS, and mycillin-containing (50 U/ml) Dulbecco's modified Eagle's medium (DMEM; Merck KGaA, Darmstadt, Germany) at $37^{\circ} \mathrm{C}$ with $5 \% \mathrm{CO}_{2}$; the cells were observed and the culture medium replaced on a daily basis. When cell confluence was $>90 \%$, they were passaged and re-seeded to an appropriate density. Cells in the logarithmic phase were used for transfection and cryopreserved.

Cell transfection. The liposomal transfection method was used. Opti-MEM $^{\text {Tм }}$ (Thermo Fisher Scientific, Inc.) was used to dilute Lipofectamine $2000(1: 1 ; 15 \mu \mathrm{l})$ and pCDGFP-C/EBP $\alpha$ plasmids ( $5 \mu \mathrm{g} ; 500 \mathrm{ng} / \mu \mathrm{l})$ with empty plasmid as the negative control; upon standing for $5 \mathrm{~min}$, they were agitated gently, left to stand for a further $20 \mathrm{~min}$, and added to SW480 cells in the logarithmic phase. After 4-6 h of incubation, the culture medium was replaced with fresh complete medium, followed by a further 24-72 $\mathrm{h}$ incubation; the medium was changed once every $24 \mathrm{~h}$. Then the $\mathrm{C} / \mathrm{EBP} \alpha$ expression level was determined with reverse transcription-quantitative PCR (RT-qPCR).

Wound-healing assay. The pCDGFP-C/EBP $\alpha$-transfected and non-transfected SW480 cells were used in a wound-healing assay. At $6 \mathrm{~h}$ after transfection, the medium was changed, a pipette tip was used to draw lines in the cell monolayer of culture dishes and PBS was used to rinse the surface 2-3 times to remove debris. The culture dishes were then incubated and the medium was replaced daily. The cell migration was observed at 4 timepoints $(0,24,48$ and 72 h); 10 observation points were selected at each timepoint, and the distance between one side of the wound to the farthest point was measured and recorded. The mean distance was then used, and the cell mobility was calculated using the following formula: Mobility=(initial scratch width-scratch width at each time point)/initial scratch width $\mathrm{x} 100 \%$.

RNA isolation and RT-qPCR. The mRNA expression levels for $\mathrm{C} / \mathrm{EBP} \alpha$ were examined by RT-qPCR using RNA isolated from pCDGFP-C/EBP $\alpha$-transfected and non-transfected SW480 cells (TRIzol ${ }^{\circledR}$ kit; Thermo Fisher Scientific, Inc.). Taq polymerase (Qiagen GmbH, Hilden, Germany) was used to add bases to primers and a PCR kit (Thermo Fisher Scientific, Inc.) was used for amplification in qPCR, and the thermocycling protocol was as follows: Pre-denaturation at $95^{\circ} \mathrm{C}$ for $10 \mathrm{~min}$, denaturation at $95^{\circ} \mathrm{C}$ for $10 \mathrm{sec}$ and $62^{\circ} \mathrm{C}$ for $30 \mathrm{sec}$, and extension at $72^{\circ} \mathrm{C}$ for $32 \mathrm{sec}$ for 40 cycles. Using $2 \mu \mathrm{g}$ RNA, cDNA was synthesized using a Superscript III first-strand cDNA synthesis kit (Invitrogen; Thermo Fisher Scientific, Inc.). qPCR was subsequently performed using a StepOne $^{\mathrm{TM}}$ Real-Time PCR machine (Applied Biosystems; Thermo Fisher Scientific, Inc.). Reactions of $20 \mu 1$ were performed using $100 \mathrm{ng} / \mathrm{ml} \mathrm{cDNA}$; the amplification of the product was measured via SYBR-Green fluorescence 


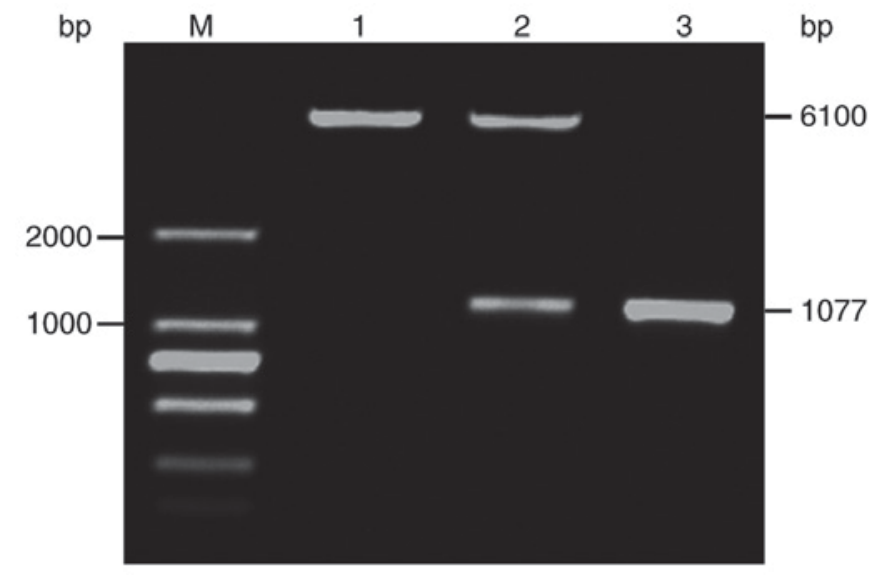

Figure 1. Double-enzyme digestion identification of recombinant plasmid pCDGFP-C/EBP $\alpha$. M, DNA markers; 1, pCDGFP digested product; 2, pCDGFP-C/EBP $\alpha$ digested products; 3, C/EBP $\alpha$ polymerase chain reaction product. $\mathrm{C} / \mathrm{EBP} \alpha, \mathrm{CCAAT} / \mathrm{enhancer}$ binding protein $\alpha$.

relative to endogenous cyclophilin, which was expressed in the comparative $\mathrm{Cq}$ format $\left(2^{-\Delta \mathrm{Cq}}\right)(11)$. The amplification thermocycling profile was $94^{\circ} \mathrm{C}$ for $0.5 \mathrm{~min}, 58^{\circ} \mathrm{C}$ for 1 $\mathrm{min}$, and $72^{\circ} \mathrm{C}$ for $1 \mathrm{~min}$, for 28 cycles. Primers for $\mathrm{C} / \mathrm{EBP} \alpha$ (forward, 5'-TCGCCATGCCGGGAGAACTCTAAC-3' and reverse, 5'-CTGGAGGTGGCTGCTCATCGGGG-3') were purchased from from GenScript (Nanjing, China). $\beta$-actin was used as an internal control (forward, 5'-CCGACAGGA TGCAGAAGGAG-3' and reverse, 5'-GGCACGAAGGCT CATCATTC-3').

Western blot analysis. Samples were centrifuged at 12,000 x g for $5 \mathrm{~min}$ at $4^{\circ} \mathrm{C}$ (Centrifuge 5804/5804 R; Eppendorf, Hamburg, Germany) and the total protein content in the supernatant was determined using an Enhanced BCA Protein Assay kit (Beyotime Institute of Biotechnology, Haimen, China). A total of $30 \mu \mathrm{g}$ protein from the cell lysates was separated by $10 \%$ SDS-PAGE and transferred to a polyvinylidene difluoride membrane. The membrane was subsequently blocked with $5 \%$ skimmed milk at room temperature for $1 \mathrm{~h}$, and incubated at $4^{\circ} \mathrm{C}$ overnight with KLF5 (cat. no. bs-2020R), MMP-2 (cat. no. bs-4599R), MMP-9 (cat. no. bs-20619R) or ECD rabbit polyclonal antibodies (dilution, 1:500; BIOSS, Beijing, China), or a mouse anti-human anti- $\beta$-actin antibody (dilution, 1:1,000; cat. no. sc-47778; Santa Cruz Biotechnology, Inc., Dallas, TX, USA). Subsequent to washing with $0.01 \mathrm{M}$ Tris-buffered saline containing $0.1 \%$ Tween-20, the membrane was incubated with horseradish peroxidase-labeled goat-anti-rabbit (cat. no. E030120-01) or anti-mouse (cat. no. E030110-01) IgG antibody (dilution, 1:1,000; EarthOx Life Sciences, Millbrae, CA, USA) at room temperature for $1 \mathrm{~h}$. A standard enhanced chemiluminescence reaction (Sangon Biotech Co., Ltd., Shanghai, China) was performed, according to the manufacturer's protocol.

Statistical analysis. SPSS statistical software 10.0 (SPSS, Inc., Chicago, IL, USA) was used for all data analysis. Experimental data were expressed as the mean \pm standard deviation, and were analyzed with a paired t test. The association of clinicopathological parameters with expression status was analyzed with the $\chi^{2}$ test. $\mathrm{P}<0.05$ was considered to represent a statistically significant difference.

\section{Results}

Expression of $C / E B P \alpha$ in $C C$ tumor and adjacent tissue samples. The CC tumor and adjacent tissue samples of from 48 patients with $\mathrm{CC}$ were analyzed with immunohistochemistry to assess the expression of $\mathrm{C} / \mathrm{EBP} \alpha$. Among the 48 normal tissue samples, 3 cases $(6.25 \%)$ exhibited the negative or low expression of $\mathrm{C} / \mathrm{EBP} \alpha$, whereas the remaining 45 cases exhibited high $\mathrm{C} / \mathrm{EBP} \alpha$ expression; among the $48 \mathrm{CC}$ tumor samples, 33 cases $(68.75 \%)$ exhibited the negative or low expression of $\mathrm{C} / \mathrm{EBP} \alpha$, whereas the remaining 15 cases exhibited high $\mathrm{C} / \mathrm{EBP} \alpha$ expression. Compared with the adjacent tissue samples, the expression of $\mathrm{C} / \mathrm{EBP} \alpha$ in $\mathrm{CC}$ tissue was significantly decreased $(\mathrm{P}<0.05)$.

Associations between C/EBP $\alpha$ expression and CC clinicopathological parameters. Among the 48 cases, the C/EBP $\alpha$ expression was not associated with such clinicopathological parameters as the sex and age of the patients, whereas it was associated with the tumor size, the TNM stage and the lymph node metastasis status $(\mathrm{P}<0.05$; Table I).

Identification of $p C D G F P-C / E B P \alpha$ plasmid. The recombinant plasmid pCDGFP-C/EBP $\alpha$ was digested using Bam $\mathrm{HI}$ and EcoRI to produce two bright bands. Comparison with the marker bands demonstrated that one band was the vector, pCDGFP (6,100 bp), and the other was the C/EBP $\alpha$ fragment $(1,077 \mathrm{bp})$, indicating that the plasmid was successfully ligated. The subsequent sequencing results further verified the construct. The enzyme digestion results are displayed in Fig. 1. The expression level of $\mathrm{C} / \mathrm{EBP} \alpha$ in the transfected cells was detected using RT-qPCR. The relative expression level of $\mathrm{C} / \mathrm{EBP} \alpha$ was increased by $>200$-fold compared with the control group (238:1). This result indicated that $\mathrm{C} / \mathrm{EBP} \alpha$ was successfully expressed after transfection.

Impacts of overexpressed C/EBP $\alpha$ on the mobility of SW480 cells. At $24 \mathrm{~h}$ in the wound-healing assay, the cell mobility rate did not significantly differ between the non-transfection and transfection groups ( $\mathrm{P}>0.05)$, whereas at 48 and $72 \mathrm{~h}$, the cell mobility rates were significantly different $(\mathrm{P}<0.05)$, indicating the overexpression of $\mathrm{C} / \mathrm{EBP} \alpha$ significantly reduced the mobility of SW480 cells (Fig. 2).

Impacts of overexpressed C/EBP $\alpha$ on tumor invasion-associated proteins. At $48 \mathrm{~h}$ after plasmid transfection, western blotting analysis was applied to determine the effect of $\mathrm{C} / \mathrm{EBP} \alpha$ overexpression on the expression of tumor invasion-associated proteins, including KLF5, MMP-2, MMP-9, and ECD. The results revealed that, compared with the non-transfection group, the protein expression levels of KLF5, MMP-2 and MMP-9 in the $\mathrm{C} / \mathrm{EBP} \alpha$-overexpression group were decreased, whereas the level of ECD was increased. The results demonstrated that the overexpression of $\mathrm{C} / \mathrm{EBP} \alpha$ reduced the expression of tumor invasion-promoting proteins, thus potentially inhibiting tumor invasion (Fig. 3). 
Table I. Relationships between $\mathrm{C} / \mathrm{EBP} \alpha$ expression and the clinicopathological parameters of colon cancer.

\begin{tabular}{|c|c|c|c|c|c|}
\hline \multirow[b]{2}{*}{ Clinicopathological parameter } & \multirow[b]{2}{*}{ Total } & \multicolumn{2}{|c|}{$\begin{array}{l}\text { Expression of C/EBP } \alpha, \\
\text { n (\% of all patients) }\end{array}$} & \multirow[b]{2}{*}{$\chi^{2}$} & \multirow[b]{2}{*}{ P-value } \\
\hline & & Low & High & & \\
\hline Total & 48 & 33 & 15 & & \\
\hline $\operatorname{Sex}(\%)$ & & & & 0.058 & 0.028 \\
\hline Male & 30 & $21(63.6)$ & $9(60.0)$ & & \\
\hline Female & 18 & $12(36.4)$ & $6(40.0)$ & & \\
\hline Age, years & & & & 0.076 & 0.074 \\
\hline$\leq 50$ & 27 & 19 (57.6) & $8(53.3)$ & & \\
\hline$>50$ & 21 & $14(42.4)$ & $7(46.7)$ & & \\
\hline Tumor diameter, $\mathrm{cm}$ & & & & 4.663 & 0.015 \\
\hline$\leq 5$ & 21 & $11(33.3)$ & 10 (66.7) & & \\
\hline$>5$ & 27 & $22(66.7)$ & $5(33.3)$ & & \\
\hline Tumor-node-metastasis stage & & & & 10.381 & 0.043 \\
\hline $1 / 2$ & 19 & $8(24.2)$ & $11(73.3)$ & & \\
\hline $3 / 4$ & 29 & $25(75.8)$ & $4(26.7)$ & & \\
\hline Lymph node metastasis & & & & 13.191 & 0.037 \\
\hline Yes & 28 & $25(75.8)$ & $3(20.0)$ & & \\
\hline No & 20 & $8(24.2)$ & $12(80.0)$ & & \\
\hline
\end{tabular}

$\mathrm{C} / \mathrm{EBP} \alpha, \mathrm{CCAAT} / \mathrm{enhancer}$ binding protein $\alpha$.

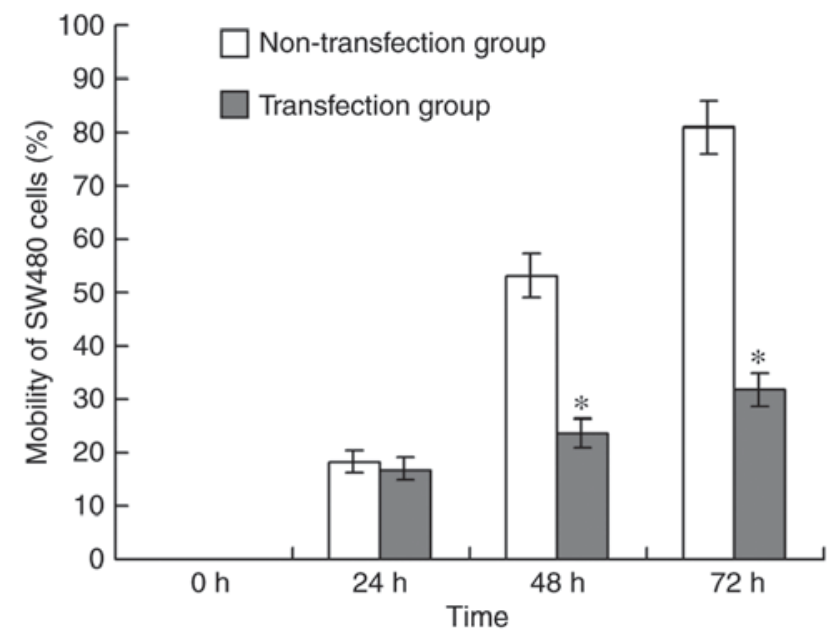

Figure 2. Effect of CCAAT/enhancer binding protein $\alpha$ transfection on the mobility of SW480 cells, as determined with a wound-healing assay. ${ }^{*} \mathrm{P}<0.05$ compared with non-transfection group.

\section{Discussion}

Tumor invasion and metastasis are processes in which cancer cells leave the primary lesion, invade surrounding tissue and continue to proliferate, ultimately resulting in the formation of new tumor lesions. This is the most critical biological property of malignant tumors. The C/EBPs are a family of transcription factors involved in the regulation of embryonic gut development in rodents that have also been detected in various types of malignancy; for example, Rask et al (12)

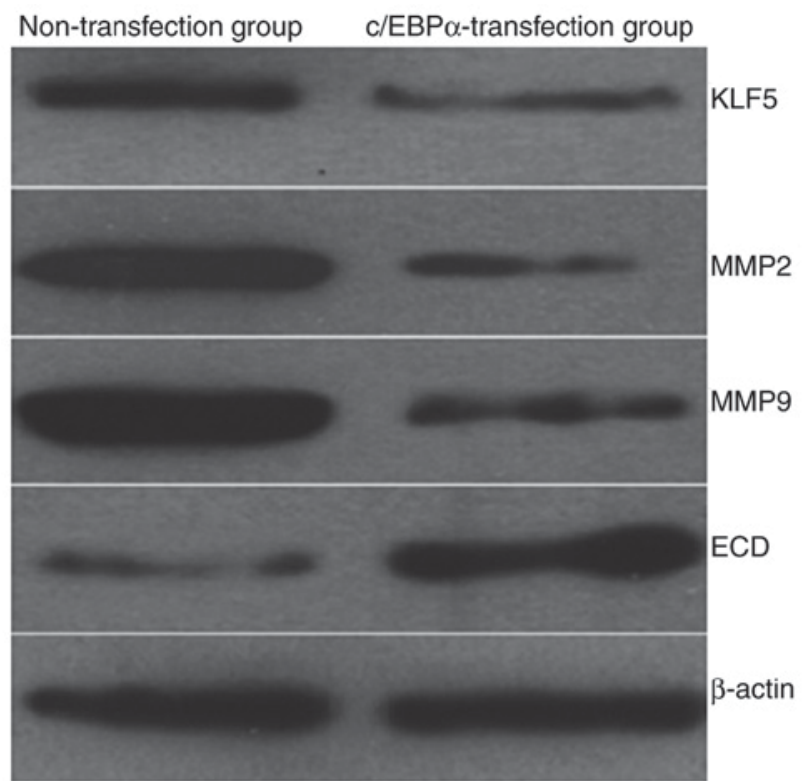

Figure 3. Effect of $\mathrm{C} / \mathrm{EBP} \alpha$ on the expression of tumor invasion-associated proteins. C/EBP $\alpha, \mathrm{CCAAT/enhancer} \mathrm{binding} \mathrm{protein} \alpha$; KLF5, Kruppel-like factor 5; MMP, metallopeptidase; ECD, E-cadherin.

identified that the expression of $\mathrm{C} / \mathrm{EBP} \beta$ was increased in all the assessed CC tumor samples compared with normal colon mucosa samples. Although the inter-patient variability was large, it was identified that liver-enriched inhibitory protein (LIP), the isoform of C/EBP $\beta$ associated with the inhibition of transcription, was expressed at higher levels in Duke's stage B tumors compared with stage A, whereas stage C 
tumors exhibited the lowest LIP expression (12). However, in the present study, it was identified that the expression of the $\mathrm{C} / \mathrm{EBP} \alpha$ subtype in $\mathrm{CC}$ tissues was significantly reduced relative to in the adjacent tissue. Thus, we hypothesize that $\mathrm{C} / \mathrm{EBP} \alpha$ may be a tumor suppressor in $\mathrm{CC}$, whereas $\mathrm{C} / \mathrm{EBP} \beta$ may increase $\mathrm{CC}$ invasiveness. This result is similar to other research in solid tumors; Yong et al (13) concluded that $\mathrm{C} / \mathrm{EBP} \alpha$ is a tumor suppressor in lung cancer, and that BMI1 is required for the oncogenic process downstream of $\mathrm{C} / \mathrm{EBP} \alpha$ loss.

The present study identified that $\mathrm{C} / \mathrm{EBP} \alpha$ was downregulated in $\mathrm{CC}$, and was associated with tumor size, the TNM stage and the lymph node metastasis status, suggesting that the low expression of $\mathrm{C} / \mathrm{EBP} \alpha$ may affect the invasion and metastasis of CC. When observing the effect of $\mathrm{C} / \mathrm{EBP} \alpha$ expression on the invasiveness of SW480 CC cells, it was identified that the SW480 cells with C/EBP $\alpha$ overexpression exhibited significantly decreased invasiveness compared with untransfected cells. In addition, in SW480 cells with overexpressed C/EBP $\alpha$, the expression of KLF5, MMP-2 and MMP-9 were reduced, whereas ECD was increased; this result was consistent with the patient data analysis. Previous studies have reported that the upregulation of KLF5, MMP-2 and MMP-9, and the low expression of ECD, promote the invasiveness of CC (14-18), which is consistent with the results of the present study.

$\mathrm{C} / \mathrm{EBP} \alpha$ has been demonstrated to inhibit cell growth via the direct repression of E2F-DP-mediated transcription (19). $\mathrm{C} / \mathrm{EBP} \alpha$ has also been observed to arrest cell proliferation through the direct inhibition of cyclin-dependent kinases 2 and $4(20,21)$. However, the detailed mechanism for the $\mathrm{C} / \mathrm{EBP} \alpha$-mediated inhibition of invasion-associated protein expression remains unclear, and should be considered in further research. In addition, the present study did not compare the pairs of CC tumor and adjacent tissues directly, so this is a limitation of the study that will be addressed in further research.

In summary, $\mathrm{C} / \mathrm{EBP} \alpha$ expression was associated with the occurrence and development of CC.

\section{Acknowledgements}

Not applicable.

\section{Funding}

The present study was supported by the Projects of Science and Research Foundation of Educational Department of Hunan (grant no. 13C831).

\section{Availability of data and materials}

The analyzed datasets generated during the study are available from the corresponding author, on reasonable request.

\section{Authors' contributions}

XJZ and LFL designed the experiment. XZL, LFL and SW reviewed the protocol. XJZ and LFL conducted the experiment. WL and LJJ wrote the manuscript. WL and LJJ performed statistical analysis. XZL and SW reviewed the manuscript.

\section{Ethics approval and consent to participate}

The study was conducted in accordance with the declaration of Helsinki, and was approved by the Ethics Committee of the University of South China. Written informed consent was obtained from all participants.

\section{Patient consent for publication}

Not applicable.

\section{Competing interests}

The authors declare that they have no competing interests.

\section{References}

1. Siegel RL, Miller KD and Jemal A: Cancer Statistics, 2016. CA Cancer J Clin 66: 7-30, 2016.

2. Shaukat A, Mongin SJ, Geisser MS, Lederle FA, Bond JH, Mandel JS and Church TR: Long-term mortality after screening for colorectal cancer. N Engl J Med 369: 1106-1114, 2013.

3. Eichhorn JM, Alford SE, Sakurikar N and Chambers TC: Molecular analysis of functional redundancy among anti-apoptotic Bcl-2 proteins and its role in cancer cell survival. Exp Cell Res 322: 415-424, 2014.

4. Cast A, Valanejad L, Wright M, Nguyen P, Gupta A, Zhu L, Shin $\mathrm{S}$ and Timchenko N: C/EBP $\alpha$-dependent pre-neoplastic tumor foci are the origin of hepatocellular carcinoma and aggressive pediatric liver cancer. Hepatology 67: 1857-1871, 2018.

5. Tan EH, Hooi SC, Laban M, Wong E, Ponniah S, Wee A and Wang ND: CCAAT/enhancer binding protein alpha knock in mice exhibit early liver glycogen storage and reduced susceptibility to hepatocellular carcinoma. Cancer Res 65: 10330-10337, 2005.

6. Chen Y, Costa RM, Love NR, Soto X, Roth M, Paredes R and Amaya E: C/EBPalpha initiates primitive myelopoiesis in pluripotent embryonic cells. Blood 114: 40-48, 2009.

7. McFie PJ, Wang GL, Timchenko NA, Wilson HL, Hu X and Roesler WJ: Identification of a co-repressor that inhibits the transcriptional and growth-arrest activities of CCAAT/enhancer binding protein alpha. J Biol Chem 281: 18069-18080, 2006.

8. Fukuchi Y, Shibata F, Ito M, Goto-Koshino Y, Sotomaru Y, Ito M, Kitamura T and Nakajima $\mathrm{H}$ : Comprehensive analysis of myeloid lineage conversion using mice expressing an inducible form of C/EBP alpha. EMBO J 25: 3398-3410, 2006.

9. Reddy SD, Pakala SB, Ohshiro K, Rayala SK and Kumar R: MicroRNA-661, a c/EBP $\alpha$ target, inhibits metastatic tumor antigen 1 and regulates its functions. Cancer Res 69: 5639-5642, 2009.

10. Benson AB III, Venook AP, Cederquist L, Chan E, Chen YJ, Cooper HS, Deming D, Engstrom PF, Enzinger PC, Fichera A, et al: Colon Cancer, Version 1.2017, NCCN clinical practice guidelines in oncology. J Natl Compr Canc Netw 15: 370-398, 2017.

11. Mestdagh P, Feys T, Bernard N, Guenther S, Chen C, Speleman F and Vandesompele J: High-throughput stem-loop RT-qPCR miRNA expression profiling using minute amounts of input RNA. Nucleic Acids Res 36: e143, 2008.

12. Rask K, Thörn M, Pontén F, Kraaz W, Sundfeldt K, Hedin L and Enerbäck S: Increased expression of the transcription factors CCAAT-enhancer binding protein-beta (C/EBBeta) and $\mathrm{C} /$ EBzeta (CHOP) correlate with invasiveness of human colorectal cancer. Int J Cancer 86: 337-343, 2000.

13. Yong KJ, Basseres DS, Welner RS, Zhang WC, Yang $\mathrm{H}$, Yan B, Alberich-Jorda M, Zhang J, de Figueiredo-Pontes LL, Battelli C, et al: Targeted BMI1 inhibition impairs tumor growth in lung adenocarcinomas with low CEBP $\alpha$ expression. Sci Transl Med 8: 350ra104, 2016. 
14. Basu N, Saha S, Khan I, Ramachandra SG and Visweswariah SS: Intestinal cell proliferation and senescence are regulated by receptor guanylyl cyclase C and p21. J Biol Chem 289: 581-593, 2014.

15. Zhen C, Chen L, Zhao Q, Liang B, Gu YX, Bai ZF, Wang K, $\mathrm{Xu}$ X, Han QY, Fang DF, et al: Gankyin promote breast cancer cell metastasis by regulating Racl activity. Oncogene 32 : 3452-3460, 2013.

16. Geng L, Sun B, Gao B, Wang Z, Quan C, Wei F and Fang XD: MicroRNA-103 promotes colorectal cancer by targeting tumor suppressor DICER and PTEN. Int J Mol Sci 15: 8458-8472, 2014.

17. Chen J, Zheng B, Wang C, Chen Y, Du C, Zhao G, Zhou Y and Shi Y: Prognostic role of microRNA-100 in various carcinomas: Evidence from six studies. Tumour Biol 35: 3067-3071, 2014.

18. Liu Y, Sheng J, Dai D, Liu T and Qi F: Smad4 acts as tumor suppressor by antagonizing lmphangiogenesis in colorectal cancer. Pathol Res Pract 211: 286-292, 2015.
19. Zaragoza K, Bégay V, Schuetz A, Heinemann U and Leutz A: Repression of transcriptional activity of C/EBPalpha by E2F-dimerization partner complexes. Mol Cell Biol 30: 2293-2304, 2010

20. Wang GL, Shi X, Salisbury E, Sun Y, Albrecht JH, Smith RG and Timchenko NA: Cyclin D3 maintains growth-inhibitory activity of C/EBPalpha by stabilizing C/EBPalpha-cdk2 and C/EBPalpha-Brm complexes. Mol Cell Biol 26: 2570-2582, 2006.

21. Wang H, Iakova P, Wilde M, Welm A, Goode T, Roesler WJ and Timchenko NA: C/EBPalpha arrests cell proliferation through direct inhibition of Cdk2 and Cdk4. Mol Cell 8: 817-828, 2001. 